\title{
Nutrient regimes in the marginal ice zone of the Greenland Sea in summer*
}

\author{
Annette Spies ${ }^{1}$, Uwe H. Brockmann ${ }^{1}$, Gerhard Kattner ${ }^{2}$ \\ ' Institut für Biochemie und Lebensmittelchemie, Universität Hamburg, Martin-Luther-King-Platz 6, D-2000 Hamburg 13, \\ Federal Republic of Germany \\ ${ }^{2}$ Alfred-Wegener-Institute for Polar and Marine Research, Am Handelshafen 12, D-2850 Bremerhaven, Federal Republic of \\ Germany
}

\begin{abstract}
The surface layer $(150 \mathrm{~m})$ mutrient distribution (nitrate and nitrite, phosphate, silicate, ammonium) in the ice edge zone of Fram Strait was investigated during summer 1984 as part of the Marginal Ice Zone Experiment (MIZEX '84). The position of the ice edge was determined by the hydrography of the region, i. e the different water masses typical of the Greenland Sea (Polar Water, Atlantic Water and Intermediate Water). Nutrient concentrations reflected the different types of water. Nutrient distribution was characterized by strong vertical stratification and large gradients at water mass boundaries. Nutrient minima were correlated with high biomass concentrations in stratified surface waters. At frontal boundaries elevated chlorophyll a values were associated with abundant nutrients. Along 5 transects through the ice edge zone, distinct ammonium maxima were found at the depth of the chlorophyll a maximum or slightly below it. The results suggest that at least 3 different nutrient regimes can be distinguished in the surface layer of the Greenland Sea ice edge zone.
\end{abstract}

\section{INTRODUCTION}

The Fram Strait region is characterized by very dynamic and variable hydrographical structures. The bottom topography determines the general circulation pattern, and surface waters probably exhibit year-long stability due to the prevailing hydrographic conditions. The relatively stationary ice edge zone is controlled by the cold Polar Water flowing southward (East Greenland Current), the warm Atlantic Water flowing northward (West Spitsbergen Current), and the prevailing wind field.

On an annual basis light is the major limiting factor for primary production in polar regions with multi-year or seasonal ice cover. Here, phytoplankton growth is restricted to the short melting period in summer or to open water areas, e.g. leads and polynyas. The ice edge zone - the region of seasonal melting and resulting stabilization of the uppermost water column - is known as a center of intense biological activity in Arctic as well as Antarctic waters (e.g. Schandelmeier \& Alexander 1981, Rey \& Loeng 1985, Smith \& Nelson 1985,

- Contribution No. 102 of the Alfred-Wegener-Institute for Polar and Marine Research.
Smith et al. 1985, 1987, Spies 1987). Ice edge primary production is important to the overall productivity of polar regions.

The biological and chemical part of the MIZEX ' 84 (Marginal Ice Zone Experiment) programme was designed to study the possible controlling mechanisms of ice edge biogenic production. Contrary to Antarctic waters where macro-nutrients are abundant all year around (e.g. Hayes et al. 1984, El-Sayed 1985), the nutrient situation in Arctic seas differs considerably with respect to the pre-bloom concentrations, differences in ice edge dynamics, and the characteristics of the water masses typical of the different domains.

During July to August 1983, Smith et al. (1985) found surface nitrate concentrations of less than $0.5 \mu \mathrm{g}$-at $1^{-1}$ and a distinct ammonium maximum at the base of the euphotic zone. Smith et al. (1987) speculate that new production following the spring bloom in the east Greenland Sea/Fram Strait area is therefore dependent on the upward flux of nitrate later in the season. MIZEX '84 confirmed the importance of mesoscale eddies in influencing the spatial and temporal variations of biological processes and nutrient supply in the marginal ice zone of the Greenland Sea.

The specific objective of this investigation was to 
determine the distribution of macro-nutrients within the marginal ice zone and in relation to the different water masses in the Greenland Sea/Fram Strait area. Mechanisms for nutrient consumption and replenishment within the marginal ice zone will be discussed.

\section{MATERIAL AND METHODS}

The study was conducted as part of the 1984 Marginal Ice Zone Experiment (MIZEX '84) in the ice edge region of the Greenland Sea/Fram Strait area. The nutrient data of 5 ice edge transects reported herein were collected from RV 'Polarstern'; Stns 174 to 182 were sampled on $18 / 19$ June, Stns 184 to 190 on 20 June, Stns 192 to 203 on 21/22 June, Stns 275 to 283 on $5 / 6$ July and Stns 288 to 294 on $7 / 8$ July. Fig. 1 shows the location of the transects, the position of the ice edge during the sampling periods, and the percentage of ice cover along the transects. The position of the ice edge varied during the study; ice information is based on NOAA satellite images (kindly provided by Dr. Strübing, Deutsches Hydrographisches Institut, Hamburg) and ice observations of the vessel's meteorological station.

Samples for nutrients (nitrate, nitrite, phosphate, silicate, ammonium) were taken from a Niskin bottle rosette system at each station. Immediately after collection, samples were processed on board using a Techni- con AutoAnalyzer-II system. The automated procedures for nitrate and nitrite analyses were based on the methods of Armstrong et al. (1967). Determination of phosphate followed the method of Murphy \& Riley (1962) with modifications by Eberlein \& Kattner (1987) Reactive silicate was measured as described in Grasshoff et al. (1983). Determination of ammonium followed an automated version of the phenol-hypochlorite method of Koroleff (1969).

\section{RESULTS}

Along 5 transects through the ice edge zone $\mathrm{T}$ and $\mathrm{S}$ sections show the distribution of the characteristic water masses in the Fram Strait region (Figs. 2 to 6). In the west, Polar Water (defined by Aagaard \& Coachman 1968, $\mathrm{T}<0{ }^{\circ} \mathrm{C}, \mathrm{S} \% \circ<34$; Fig. 6) is flowing southward out of the Arctic Ocean and transporting a stream of ice to lower latitudes. In the northern transects (Figs. 2 to 5), Polar Water mixed with meltwater was restricted to the very top layer of the water column. Towards the east, the northbound West Spitsbergen Current, carrying Atlantic Water (defined by Swift \& Aagaard $1981 ; \mathrm{T}>3{ }^{\circ} \mathrm{C}, \mathrm{S} \%>34.9$ ) northward, is recirculated southward into the East Greenland Current (Paquette et al. 1985); this Return Atlantic Current has a core of relatively warm and saline Atlantic Intermediate Water $\left(\mathrm{T}=0.5\right.$ to $3^{\circ} \mathrm{C}, \mathrm{S} \%$ o= 34.9 ).

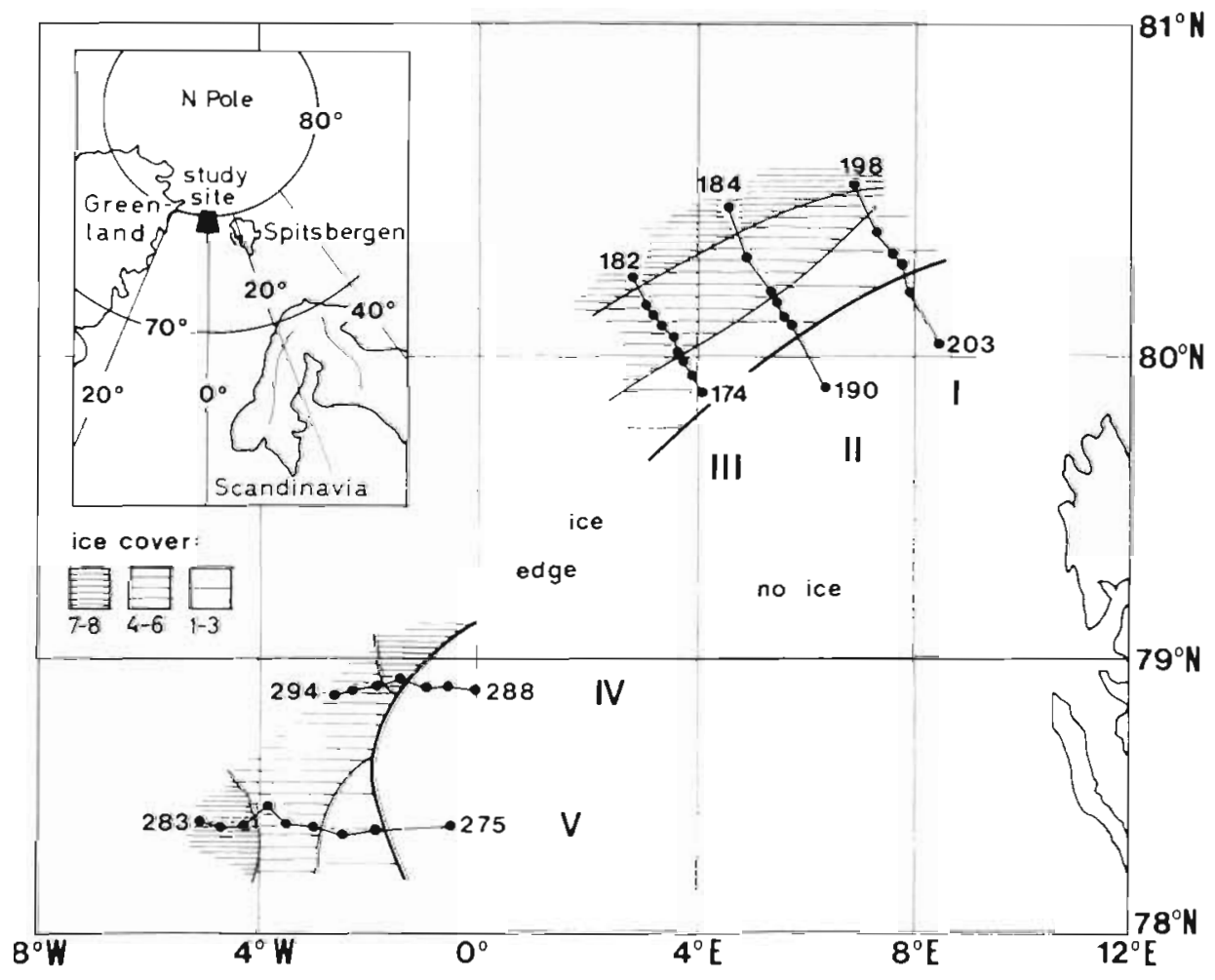

Fig. 1. Location of ice edge transects (I to $V$ ) in Fram Strait during MIZEX ' 84 . Ice cover is given in parts of ten 

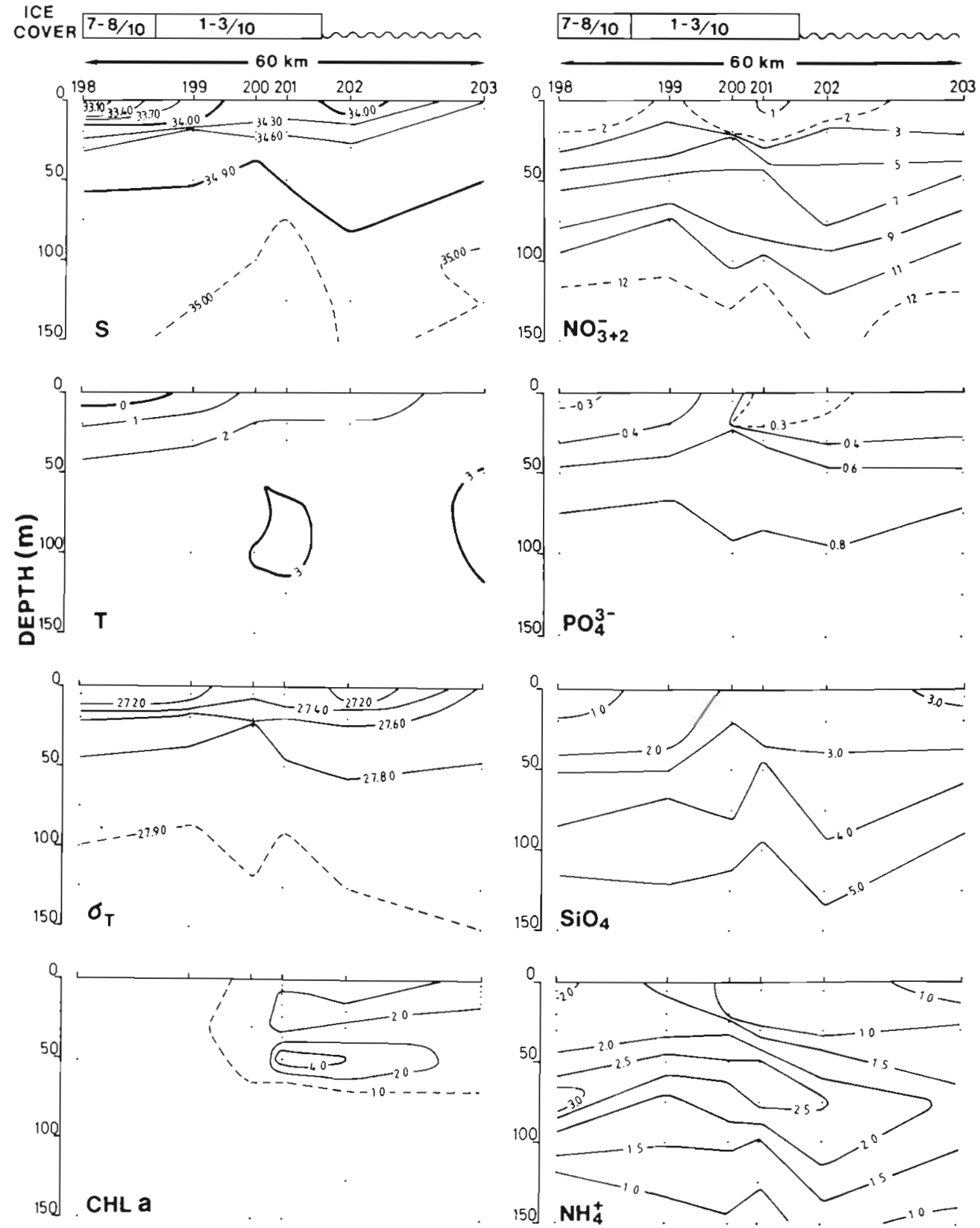

Fig. 2. Transect I: distribution of salinity $(\%)$, temperature $\left({ }^{\circ} \mathrm{C}\right)$, density, chlorophyll a $\left(\mu \mathrm{g} \mathrm{l}^{-1}\right)$, nitrate + nitrite, phosphate, silicate, and ammonium (all nutrients: $\mu \mathrm{g}$-at $\mathrm{l}^{-1}$ ). Water mass boundaries are indicated by thick lines. Dots indicate sampling depth

Transects I and II run across the Yermak Plateau; the total water depth varied between 499 and $883 \mathrm{~m}$. The changes in bottom topography cause a branching of the northward flowing current. Separate cores of warm Atlantic Water are indicated in Figs. 2 and 3. The water column exhibited a banded structure with fresher and colder water on top of the Intermediate Water, the latter overlying the warm and salty Atlantic Water. Transects III and IV (Figs. 4 and 5) cut through eddylike features (Stns 181 to 174 , Stns 292 to 290); water depth along the transects was more than $1453 \mathrm{~m}$. Transect $V$ covered a section extending from the East Greenland Shelf $(415 \mathrm{~m})$ eastward into the middle of Fram Strait $(2869 \mathrm{~m})$. This most southern transect (Fig. 6) is a section through the Polar Front in the west and the Arctic Front in the east; here, the frontal zones are less than $50 \mathrm{~km}$ apart.

At the extremely low temperatures in high Arctic domains, density is closely tied to salinity (Figs. 2 to 6 ). Most of the stations were located in the pack ice zone, 

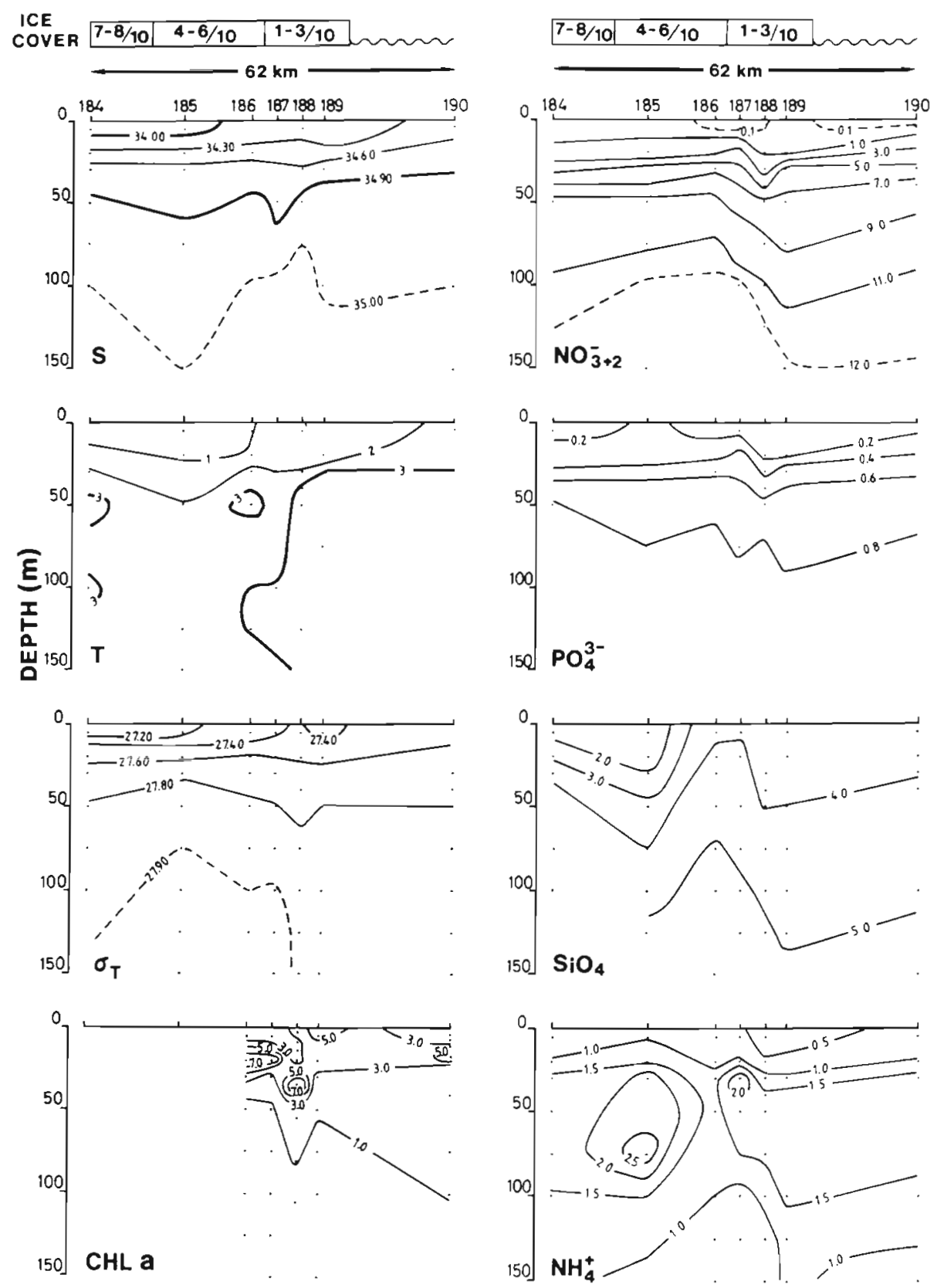

Fig. 3. Transect II: legend as in Fig. 2

where ice cover varied from less than $1 / 10$ to $8 / 10$. The thickness of the ice increased with latitude; thin ice was found along Transects IV and V, whereas Transects I to III were located in medium to thick $1 \mathrm{yr}$ pack ice. In June/July 1984 the pack ice was still melting, thus lowering surface salinities and increasing the stability of the water column. Since the decrease in surface salinity (due to meltwater) relative to that at $100 \mathrm{~m}$ depth was less than $5 \%$, dilution effects alone did not reduce nutrient concentrations to in situ values.

In the ice edge zone, the inorganic nutrient concen- trations were characterized by the different source waters; in general, the Polar Water had lower nitrate and higher silicate values than the Atlantic Water. The nutrient ratios reflect the differences in absolute concentrations (Table 1). The nitrate and phosphate sections along the transects exhibited great similarity (Figs. 2 to 6). Largest gradients of both these macronutrients were found between 20 and $50 \mathrm{~m}$ depth or were associated with water mass boundaries. Nitrate concentrations of less than $0.1 \mu \mathrm{g}$-at $1^{-1}$ were found in the top $10 \mathrm{~m}$ at the open water Stn 190 (Fig. 3), and at 

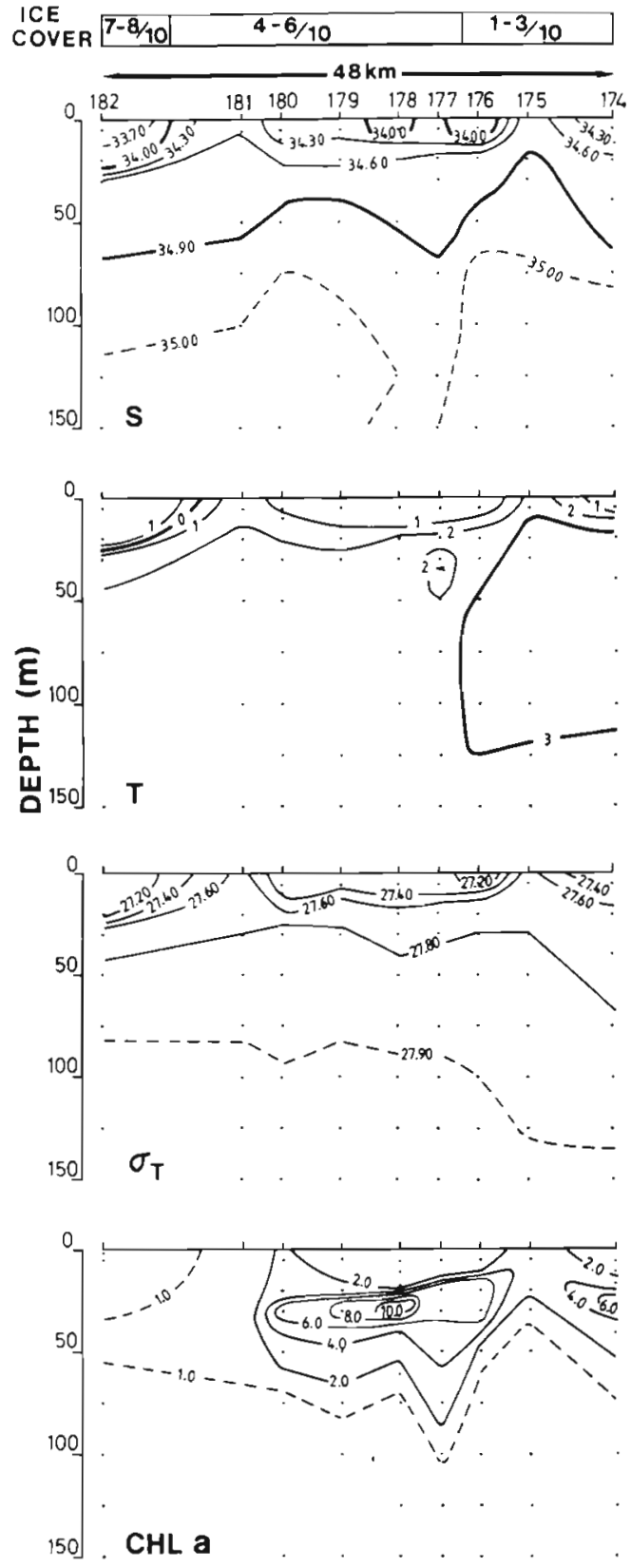
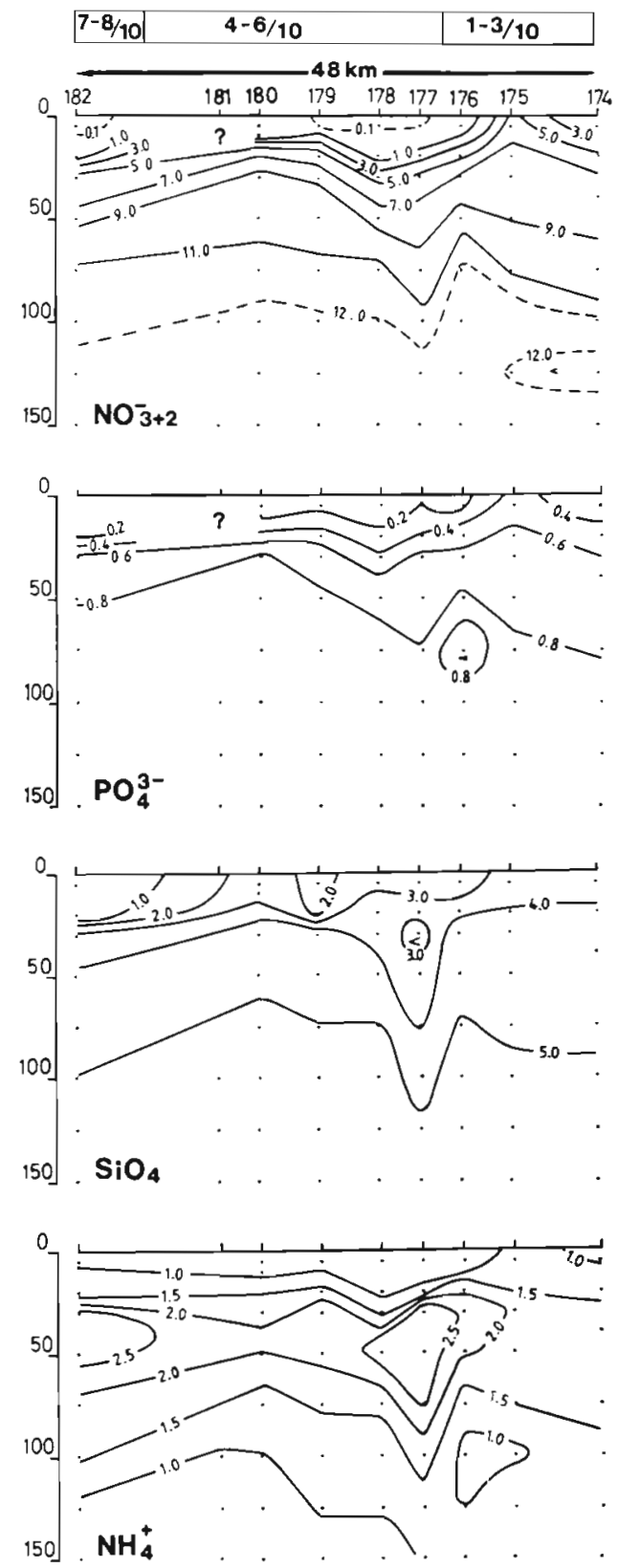

Fig. 4. Transect III: legend as in Fig. 2

stations in the ice edge zone, where ice cover varied between $3 / 10$ and 4 to $6 / 10$ (Stns 186 to 188 , Fig. 3; Stns 177 to 179 , Fig. 4; Stn 290, Fig. 5). Under dense pack ice ( 7 to $8 / 10$ ), nitrate concentrations showed great horizontal variability; values ranged from less than $0.1 \mu \mathrm{g}$ at $\mathrm{l}^{-1}$ at Stn 182 (Fig. 4) to more than $4 \mu \mathrm{g}$-at $\mathrm{l}^{-1}$ at Stns 281 to 283 (Fig. 6). In surface waters of frontal regions, nitrate concentrations were always higher than $2 \mu \mathrm{g}$-at $1^{-1}$ (Stn 199, Fig. 2; Stn 175, Fig. 4; Stn 277, Fig. 6).

Nitrate and phosphate concentrations were negatively correlated with autotrophic biomass, indicating that uptake by phytoplankton was the major factor in reducing nutrient levels in the euphotic zone. Chlorophyll a maxima were found at the depth of the nutricline, or were associated with water mass boundaries. The negative correlation between silicate and chlorophyll a was less pronounced. Along Transect II (Stns 186 to 189, Fig. 3), silicate concentrations higher than $3 \mu \mathrm{g}$-at $1^{-1}$ were measured in the presence of autotrophic biomass maxima. Lowest silicate concentrations $\left(<1 \mu \mathrm{g}\right.$-at $1^{-1}$ ) were found in the top surface layer of Stns 198 (Fig. 2) and 182 (Fig.4) underneath 

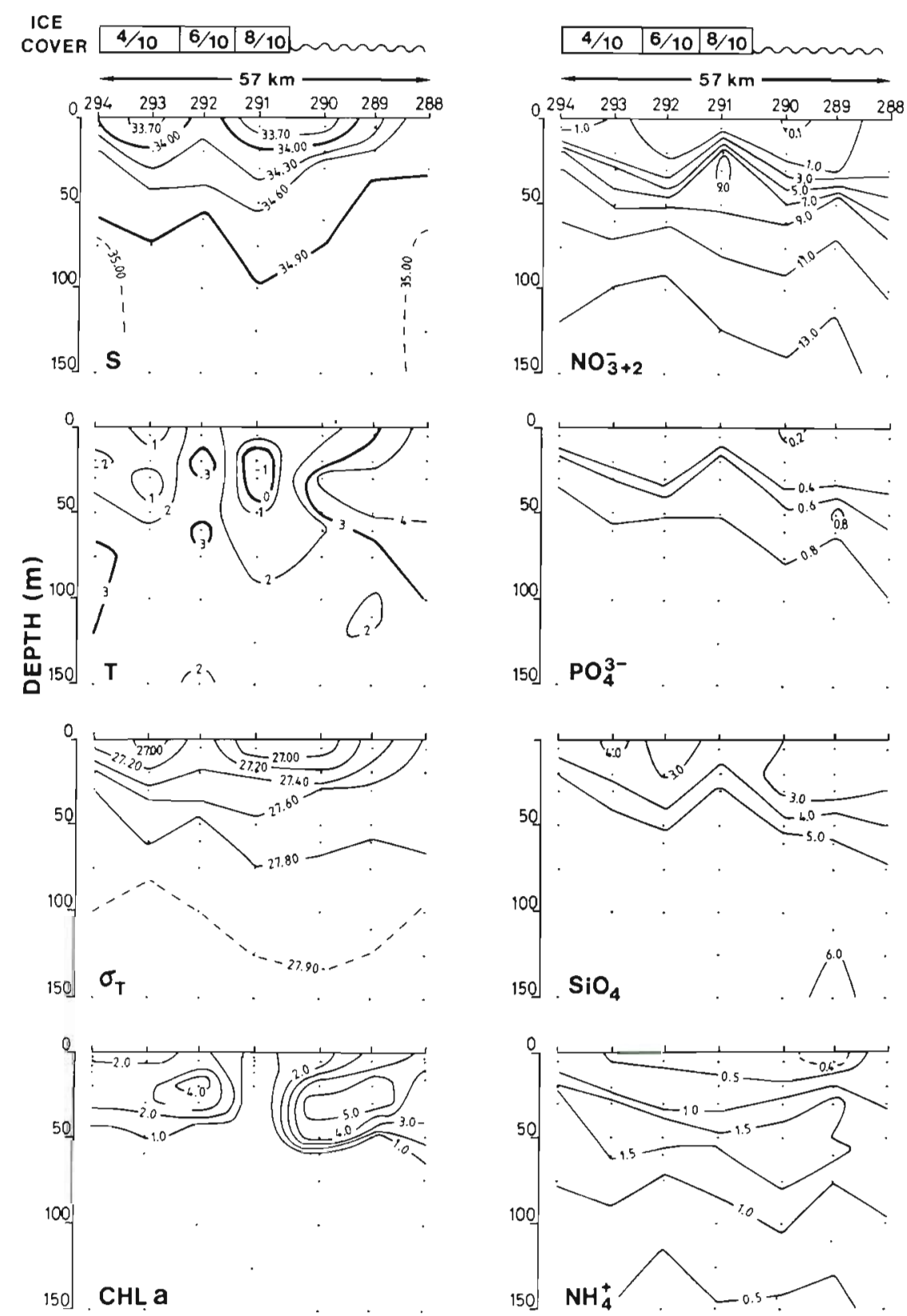

Fig. 5. Transect IV: legend as in Fig. 2

the dense pack ice cover. Transect $V$ cut through a silicate jet running along the East Greenland Shelf break.

All sections show ammonium maxima at varying depth between 20 and $80 \mathrm{~m}$. Along the transects, highest ammonium concentrations ranged from 1.76 to $3.11 \mu \mathrm{g}$-at $\mathrm{I}^{-1}$, and were associated with the depth of the chlorophyll a maximum (Transects II to IV, Figs. 3 to 5) or were found slightly below the phytoplankton biomass accumulation (Transects I and V. Figs. 2 and 6). Ammonium values higher than $2.5 \mu \mathrm{g}$-at $\mathrm{l}^{-1}$ were also observed below very dense ice cover where chlorophyll a concentrations were less than $1.0 \mu \mathrm{g} \mathrm{i}^{-1}$ (Transect III, Fig. 4).

\section{DISCUSSION}

The marginal ice zone in the Greenland Sea/Fram Strait area differs considerably from those in other polar regions, e.g. the Bering or Barents Seas. The latter shelf seas are characterized by an annually 

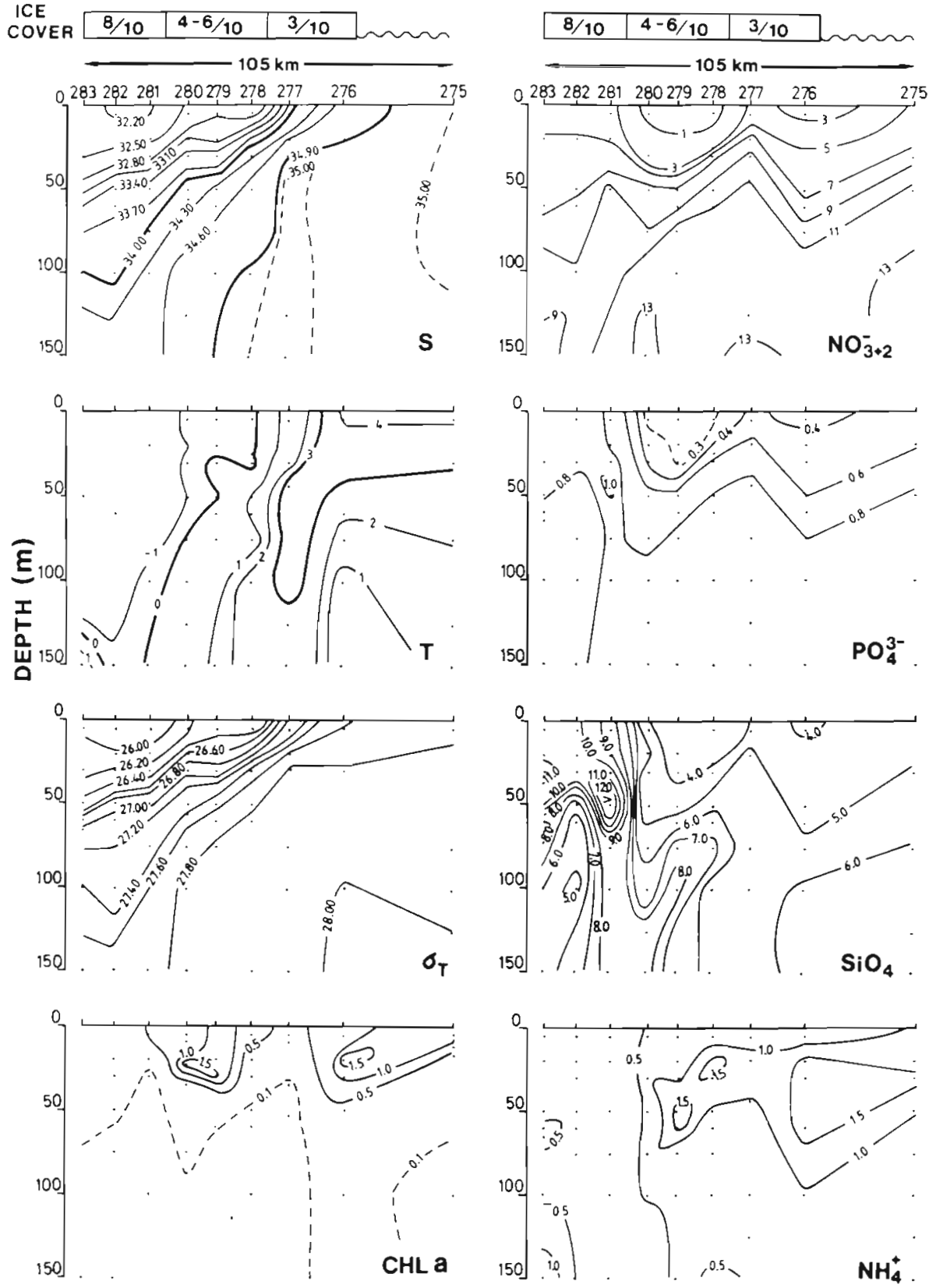

Fig. 6. Transect V: legend as in Fig. 2

advancing and retreating ice sheet of up to $400 \mathrm{~km}$ (Alexander \& Niebauer 1981, Niebauer \& Alexander 1985, Rey \& Loeng 1985). The melting of this ice sheet increases mixed layer stability and initiates a typical spring bloom of small, chainforming diatoms (Schandelmeier \& Alexander 1981, Rey \& Loeng 1985). These typical ice edge blooms have been found in the Greenland Sea as well, but are restricted to the shelf areas of the East Greenland Coast (Spies 1987).

In Fram Strait, melting processes at the ice edge are not limited to periods of solar insolation, they occur all year around due to the warm Atlantic Water which flows northward in the West Spitsbergen Current. Thus, the large-scale circulation of the area determines the ice edge position throughout the year. Frontal processes (Arctic and Polar Front) co-occur spatially with semi-permanent eddies and ice edge dynamics. The multitude of meso- and large-scale processes makes it difficult to separate the influence of one factor from the other. In addition, melting ice floes are constantly moving in response to wind (Johannessen et al. 1983) or other forces such as current jets (Paquette et al. 1985), 
Table 1. Inorganic nutrient ratios in the different water masses of Fram Strait marginal ice zone

\begin{tabular}{|c|c|c|c|}
\hline Depth (m) & $N: P$ & Si : N & $\mathrm{Si}: \mathrm{P}$ \\
\hline \multicolumn{4}{|c|}{ Polar Water $\left(\mathrm{T}<0{ }^{\circ} \mathrm{C} ; \mathrm{S} \%<34.0\right)$} \\
\hline 5 & $0.2-5.9$ & $0.7-10.8$ & $0.8-17.7$ \\
\hline 60 & $9.7-11.3$ & $0.8-1.0$ & $9.0-10.2$ \\
\hline \multicolumn{4}{|c|}{ Atlantic Intermediate Water ( $\mathrm{T}=0.5$ to $3{ }^{\circ} \mathrm{C} ; \mathrm{S} \%=34.0$ to 34.9 ) } \\
\hline 5 & $0.1-6.8$ & $0.4-41.0$ & $4.5-34.7$ \\
\hline 75 & $9.5-13.5$ & $0.4-0.7$ & $4.6-8.9$ \\
\hline \multicolumn{4}{|c|}{ Atlantic Water $\left(T>3{ }^{\circ} \mathrm{C} ; \mathrm{S} \%\right.$} \\
\hline 5 & 10.8 & 0.9 & 9.5 \\
\hline 75 & $12.5-14.3$ & $0.4-0.5$ & $5.6-6.6$ \\
\hline
\end{tabular}

thus, lowering surface salinities during ice melt and shading autotrophic algal populations.

All stations with $8 / 10$ ice cover had little biomass (chlorophyll a $<1.0 \mu \mathrm{g} \mathrm{l^{-1 }}$ ). Typical spring diatoms (Spies 1987), i.e. small chainforming Chaetoceros spp. and flat ribbon-shaped colonies of Nitzschia spp. (section Fragilariopsis), were found only at stations with relatively dense pack ice; in June/July 1984, the phytoplankton assemblage in the Fram Strait marginal ice zone was dominated by a summer population of flagellates and a diatom population of great diversity (Baumann, RWTH Aachen, FRG, pers. comm.). Silicate concentrations of 2 to $5 \mu \mathrm{g}$-at $1^{-1}$ co-occurred with chlorophyll a maxima indicating the growth of algal populations without siliceous skeletons (Figs. 2 and 3). Indeed, high percentages of autotrophic flagellates, predominantly Phaeocystis pouchetii and unidentified nano-flagellates, have been reported from these areas by Smith et al. (1987).

The most northern Transects I and II (Figs. 2 and 3) extend across the Yermak Plateau. Here, the surface lenses of fresher and colder water may originate rather from melting processes than be a representation of a thinly spread Polar Water layer (Quadfasel et al. 1987). The region is characterized by weak and irregular surface currents (Quadfasel et al. 1987). The low surface nutrient concentrations along Transects I and II and depleted silicate concentrations at stations between the transects (unpubl. data) together with the flow measurements indicate that mixing in this area is extremely reduced. Here, primary production in the water column is limited by the initial pre-spring nitrate and silicate concentrations.

Generally, nitrogen is considered to be the limiting macronutrient for autotrophic growth in the marine environment (Antia et al. 1963, Ryther \& Dunstan 1971). All N:P ratios calculated for the different water masses in the Greenland Sea were less than the Redfield Ratio (Redfield et al. 1963). Ratios at 60 and $75 \mathrm{~m}$ depth represent values from below the nutricline, and were always higher than those at $5 \mathrm{~m}$ depth, where nitrogen concentrations were reduced due to uptake by phytoplankton. Since diatoms utilize nitrogen and silicon in an atom ratio of 2 or $3 \mathrm{Si}$ to $1 \mathrm{~N}$ (Sakshaug \& Holm-Hansen 1984), the low silicate concentrations (< $2 \mu \mathrm{g}$-at $\mathrm{I}^{-1}$ ) in the top surface layer of the Yermak Plateau stations (Transects I to III) may be growthlimiting for some diatom species. Nevertheless, silicate limitation is probably secondary to nitrogen in controlling productivity in the area. Phosphorus is seldom limiting in the marine environment due to rapid recycling by zooplankton. In the absence of grazers, phosphate concentrations can decrease to very low values (Antia et al. 1963). Concentrations as low as $0.11 \mu \mathrm{g}$-at $1^{-1}$ were found along Transects II and III.

In the vicinity of the Polar and Arctic Fronts, abundant nutrients were associated with relatively low chlorophyll a concentrations of 1.74 to $1.78 \mu \mathrm{g} \mathrm{l} \mathrm{l}^{-1}$ (Transect V, Fig. 6). Since primary production at water mass boundaries is not limited by nutrients, other factors control autotrophic biomass accumulation. It is possible that the region was covered by dense pack ice until recently; thus, phytoplankton growth had been light-limited and exponential growth had not started yet. On the other hand, it is possible to have relatively low standing crops while material and energy fluxes are of different orders of magnitude (Walsh 1969). Along Transect V (Fig. 6), the ammonium maxima in close vicinity to the chlorophyll a peak values may indicate the activity of grazers. Biomass will accumulate only when the loss rates, e.g. advection, sinking and grazing, are less than the growth rates of the algae.

During MIZEX '83, ammonium maxima were first reported from the East Greenland Sea by Smith et al. (1985); peak concentrations of 1.0 to $2.0 \mu \mathrm{g}$-at $1^{-1}$ were found at the base of the euphotic zone together with copepod aggregations in the upper 25 to $50 \mathrm{~m}$ surface layer. These populations did not undergo vertical migration (Smith 1988), In summer 1984 elevated concentrations of pheophytin $a$ and a high percentage of 
microflagellates were observed in the ice edge zone in Fram Strait (Smith et al. 1987). Based on these observations, the ammonium maxima below the nutricline found in this study resulted from the combined effects of nutrient recycling by zooplankters, bacterial decomposition, and reduced phytoplankton uptake at depth. In this regeneration process, the role of larger zooplankters may be less important than recycling by microzooplankton and bacteria (Smith et al. 1985). Based on their ${ }^{15} \mathrm{~N}$-uptake studies in Fram Strait, Smith \& Kattner (1988) conclude that the majority of primary production in the area is supported by nitrate; regenerated nitrogen will become increasingly important when nitrate levels in the stratified surface layer become exhausted after the spring bloom event. No ammonium maxima were observed in March 1987 during a study which took place before any measurable phytoplankton growth (Smith \& Kattner 1988).

Our results reveal the close relationship between the hydrography of an area, nutrient distribution and autotrophic biomass. Three different nutrient regimes could be distinguished in the Fram Strait marginal ice zone: firstly, rapid uptake of nutrients with depletion of nitrate in a shallow highly stratified meltwater surface layer during the spring bloom. This process is similar to the nutrient regimes reported from the Bering and Barents Sea or other polar shelf areas, where ambient nitrogen levels limit autotrophic growth throughout the summer (Rey \& Loeng 1985). Secondly, nitrogen is resupplied to the surface by mixing processes like the formation of eddies with subsequent upwelling of nutrient-rich Atlantic Water (Smith et al. 1987) or by continuous lateral mixing at fronts. On a seasonal basis, the latter processes can lead to higher annual production than the spring outburst of algal growth initiated by meltwater stabilization. Thirdly, the distinct ammonium maxima were indicative of active nutrient regeneration by bacteria and secondary producers.

Acknowledgements. This research was supported by the German Federal Research Board (DFG) grant AL 46/5-1, the SFB 94 and SFB 318. We thank I. Büns and M. Schütt for field and laboratory assistance and the Alfred-Wegener-Institute for Polar- and Marine Research for the opportunity to work on RV 'Polarstern'. Hydrographic data were collected by K.-P. Koltermann, Deutsches Hydrographisches Institut, Hamburg, and P. Jones, Bedford Institute of Oceanography, Dartmouth, NS, Canada. W. O. Smith, Naval Postgraduate School, Monterey, CA, USA and his colleagues kindly provided the chlorophyll a data. G. Heisler and G. Sopha prepared the drawings, R Lucht typed the manuscript.

\section{LITERATURE CITED}

Aagaard, K., Coachman, L. K. (1968). The East Greenland Current north of Denmark Strait, 1. Arctic 21: 181-200
Alexander, V., Niebauer, H. T. (1981). Oceanography of the eastern Bering Sea ice-edge in spring. Limnol. Oceanogr. 26: $1111-1125$

Antia, N. J., McAllister, C. D., Parsons, T. R., Stephens, K., Strickland, J. D. H. (1963). Further measurements of primary production using a large-volume plastic sphere. Limnol. Oceanogr. 8: 166-183

Armstrong, F. A. J., Stearns, C. R., Strickland, J. D. H. (1967), The measurement of upwelling and subsequent biological processes by means of the Technicon Autoanalyzer and associated equipment. Deep Sea Res. 14: 381-389

Eberlein, K., Kattner, G. (1987). Automatic method for the determination of ortho-phosphate and total dissolved phosphorus in the marine environment. Fresenius Z. anal. Chem. 326: 354-357

El-Sayed, S. Z. (1985). Plankton of the Antarctic seas in key environments. In: Bonner, W. N., Walton, D. W. H. (eds.) Antarctica. Pergamon Press, Oxford, p. 135-153

Grasshoff, K., Ehrhardt, M., Kremling, K. (1983). Methods of seawater analysis. Verlag Chemie, Weinheim

Hayes, P. K., Whitaker, T. M., Fogg, G. E. (1984). The distribution and nutrient status of phytoplankton in the Southern Ocean between $20^{\circ}$ and $70^{\circ} \mathrm{W}$. Polar Biol. 3: 153-165

Johannessen, O. M., Johannessen, J. A., Morison, J., Farrelly, B. A., Svendsen, E. A. S. (1983). Oceanographic conditions in the marginal ice zone north of Svalbard in early fall 1979 with an emphasis on mesoscale processes. J. geophys. Res. 88: 2755-2769

Koroleff, F. (1969). Direct determination of ammonia in natural waters as indophenol blue. Coun. Meet. int. Coun. Explor Sea C.M.-ICES/C: 9

Murphy, J., Riley, J. P. (1962). A modified single solution method for the determination of phosphate in natural waters. Analytica chim. Acta 27: 31-36.

Niebauer, H. J., Alexander, V (1985). Oceanographic frontal structure and biological production at an ice edge. Cont. Shelf Res. 4: 367-388

Paquette, R. G., Bourke, R. H., Newton, J. F., Perdue, W. F (1985). The east Greenland polar front in autumn. J. geophys. Res. 90: 4866-4882

Quadfasel, D., Gascard, J.-C., Koltermann, K.-P. (1987). Large-scale oceanography in Fram Strait during the 1984 Marginal Ice Zone Experiment. J. geophys. Res. 92: 6719-6728

Redfield, A. C., Ketchum, B. H., Richards, F. A. (1963). The influence of organisms on the compositon of seawater. In: Hill, M. N. (ed.) The sea, Vol. II. Wiley-Interscience, New York, p. 26-77

Rey, F., Loeng, H. (1985). The influence of ice and hydrographic conditions on the development of phytoplankton in the Barents Sea. In: Gray, J. S., Christiansen, M. E. (eds.) Marine biology of polar regions and effects of stress on marine organisms. John Wiley \& Sons Ltd., Chichester, p. $49-63$

Ryther, J. H., Dunstan, W. M. (1971). Nitrogen, phosphorus, and eutrophication in the coastal marine environment. Science 171: 1008-1013

Sakshaug, E., Holm-Hansen, O. (1984). Factors governing pelagic production in polar oceans. In: Holm-Hansen, $\mathrm{O}$. Bolis, L., Gilles, R. (eds.) Marine phytoplankton and productivity. Lecture notes on coastal and estuarine studies. Springer-Verlag, Berlin, p. 1-18

Schandelmeier, L., Alexander, V. (1981). An analysis of the influence of ice on spring phytoplankton population structure in the southeast Bering Sea. Limnol. Oceanogr. 26 935-943

Smith, S. L. (1988). Copepods in Fram Strait in summer 
distribution, feeding, and metabolism. J. mar. Res. (in press)

Smith, S. L., Smith, W. O., Codispoti, L. A., Wilson, D. L (1985). Biological observations in the marginal ice zone of the East Greenland Sea. J. mar Res. 43: 693-717

Smith, W. O. Jr, Baumann, M. E. M., Wilson, D. L., Aletsee, L. (1987). Phytoplankton biomass and productivity in the marginal ice zone of the Fram Strait during summer 1984 J. geophys. Res. 92: 6777-6786

Smith, W. O., Kattner, G. (1988). Nitrogen uptake and phytoplankton growth in the marginal ice zone of the Fram Strait. Rapp. P.-v. Réun. Cons. int. Explor. Mer Ser. ICES (in press)
Smith, W. O., Nelson, D. M. (1985). Phytoplankton bloom produced by a receding ice edge in the Ross Sea: spatial coherence with the density field. Science 227: 163-166

Spies, A. (1987). Phytoplankton in the marginal ice zone of the Greenland Sea during summer 1984. Polar Biol. 7 : 195-205

Swift, J. H., Aagaard, K. (1981). Seasonal transitions and water mass formation in the Iceland and Greenland seas. Deep Sea Res. 28A: 1107-1129

Walsh, J. J. (1969). Vertical distribution of Antarctic phytoplankton. II. A comparison of phytoplankton standing crops in the southern ocean with that of the Florida Strait. Limnol. Oceanogr 14:86-94

This article was submitted to the editor: it was accepted for printing on June 1, 1988 